\title{
Differentiation of Growth Hormone- and Prolactin-containing Acidophils with Peroxidase-labeled Antibody '
}

\author{
BURTON L. BAKER, A. REES MIDGLEY, JR,, BRIAN E. GERSTEN AND \\ YA-YEN YU \\ Departments of Anatomy and Pathology, The University of Michigan \\ Medical School, Ann Arbor, Michigan 48104
}

\begin{abstract}
In order to verify the concept that growth hormone and prolactin are contained in two different populations of acidophils, sections of Bouin-fixed rat hypophyses were stained immunochemically. For this purpose the histochemical demonstration of peroxidase was utilized after sequential application to the tissue section of rabbit antiserum to human growth hormone (or antiserum to rat prolactin) followed by application of peroxidase-labeled sheep antiserum to rabbit gamma-globulin. It was found that growth hormone cells and prolactin cells, when revealed immunochemically, corresponded structurally to cell types that could be differentiated with reasonable certainty in sections stained with the Masson trichrome procedure. When delineated immunochemically, growth hormone cells were larger and more densely arranged in the adult male than in the intact female; they exhibited little change in the female after ovariectomy. In contrast, prolactin cells were large and frequent in the female hypophysis but were small and less frequent in the male and in the female after ovariectomy. By double-staining, growth hormone and prolactin cells were differentiated in the same section. It was concluded that (a) growth hormone and prolactin are contained in, and presumably secreted by, two different populations of acidophils; and (b) the Masson procedure permits a reasonably accurate differentiation of the two cell types.
\end{abstract}

By means of chemical staining procedures (Dawson and Friedgood, '65; Sanders and Rennels, '59; Purves, '61) and electron microscopy (Hedinger and Farquhar, '57), acidophils in the hypophyseal pars distalis of the rat may be subdivided into two types. The cells of one type tend to be arranged in rows alongside sinusoids, contain granules measuring not more than $350 \mathrm{~m} \mu$ in diameter, and in adult rats have a small Golgi apparatus. These cells are believed to secrete growth hormone. Acidophils of the second type usually occur singly, possess cytoplasmic processes ending on sinusoids, often have a large Golgi apparatus, and contain sparsely distributed granules measuring up to $700 \mathrm{~m} \mu$ in diameter. This cell type is the probable source of prolactin. Of still less certain identity is a third form of acidophil that according to Herlant ('64) secretes corticotropin in the rat.

The development of immunochemical staining methods has given hope that the functional roles of the pituitary cell types can be demonstrated conclusively. Using fluorescein-labeled antibody to human growth hormone, Leznoff et al. ('60) localized this hormone in acidophils of the human hypophysis; a similar result was obtained in the rat by Parker et al. ('65) with antibody to porcine growth hormone. Similarly, Emmart et al. implicated acidophils as being the source of prolactin in the cat ('63) and rat ('65). After Rümke and Ladiges ('65) had found that growth hormone and prolactin are contained in different acidophilic cells in hypophyses of several species, Shiino and Rennels ('66) demonstrated that growth hormone- and prolactin-containing acidophils could be differentiated in a single section by use of antibodies conjugated with different fluorescent dyes; Nayak et al. ('68) confirmed this observation in beef. Nevertheless in spite of these provocative observations, limitations inherent in methods for immunochemical staining based on fluores-

Received Dec. 12, '68. Accepted Jan. 21, '69.

1 Supported in part by USPHS research grants HD 03159-01A1 and HD 02193, and a grant from the University of Michigan Horace $H$. Rackham School of Graduate Studies. 
cence prevented these workers from differentiating the structure of the two types of acidophils with complete certainty, and from correlating intracellular distribution of hormone with cell structure.

A procedure for localizing tissue antigens with peroxidase-labeled antibody, as developed by Nakane and Pierce ('67) and applied by Nakane ('68) to the hypophysis, makes possible a clear delineation of cell types. By utilizing this method in conjunction with chemical staining, the aims of our study were to (a) confirm the observation that growth hormone- and prolactin-containing cells ${ }^{2}$ represent two populations of acidophils, (b) verify the specificity of the immunochemical reaction in growth hormone and prolactin cells by determining if sex and ovariectomy affect their incidence and structure in a predictable manner, and (c) correlate the structure and distribution of the two cell types as revealed by immunochemical staining with the cells as they appear in sections stained with the Masson procedure.

\section{MATERIALS AND METHODS}

Immunochemical staining was carried out according to the procedure of Nakane and Pierce ('67), which consists of the following essential steps. First, rabbit antiserum to the hormone was applied to a pituitary section. Second, sheep antiserum to rabbit gamma-globulin conjugated with peroxidase was applied to the section. Third, the section was stained histochemically for the demonstration of peroxidase, thus delineating the cells that contain the hormonal antigen. Three, 3'diaminobenzidine (DAB) and $\alpha$-naphthol were used as substrates, with the reaction product of $\alpha$-naphthol being revealed by subsequent staining with pyronin. By means of the Nakane ('68) double-staining procedure, growth hormone and prolactin cells were also demonstrated in the same section. This method entailed staining for one hormone after which antibody to that hormone was dissociated from the section by immersion of the slide in $\mathrm{HCl}$ ( $\mathrm{pH} 2.0$ ) with constant stirring. Then, the section was stained for the second hormone using a different substrate for peroxidase. Proof of complete dissociation of the first antibody applied to the section was obtained by the absence of staining following a second treatment with peroxidase-labeled anti-gamma-globulin and subsequent incubation in the peroxidase substrate. Finally, after immunochemical demonstration of growth hormone and prolactin cells with a-naphthol-pyronin, the stain was removed from some sections by immersion in absolute ethanol and the section then restained with the Masson ('28) procedure to permit correlation of the cells revealed by the two methods.

Antiserum to human growth hormone (anti-HGH) ${ }^{3}$ was obtained from a rabbit that had been injected nine times over a period of ten months with $\mathrm{HGH}$ (Raben, lots 12,14). Antiserum to rat prolactin (anti-RP) was obtained by emulsifying rat prolactin (HIV-8-C) prepared by S. Ellis and injecting a rabbit with $0.4 \mathrm{mg}$ of the hormone together with Freund's adjuvant three times at intervals of three weeks, with the blood being drawn two weeks after the last injection. This antiserum has been used also in development of a radioimmunoassay for rat prolactin (Niswender et al., '68). Sheep anti-rabbit gamma-globulin was conjugated with peroxidase (Sigma Type II) according to the method of Nakane and Pierce ('67).

Several procedures were carried out to validate the specificity of the immunochemical staining procedures. Substitution in the Nakane-Pierce procedure of normal rabbit serum or rabbit antiserum to egg albumen for antiserum to a hormone, or omission of the gamma-globulin-peroxidase conjugate, eliminated staining of the cells in question. In the absence of any prior treatment, incubation of pituitary sections in the peroxidase substrate did not stain parenchymal cells thus showing that pseudoperoxidase was not being revealed. In order to remove contaminating antibidies anti-HGH was absorbed with ovine prolactin (NIH-P-S-6) and anti-RP with bovine growth hormone (Armour). In neither case was the effectiveness of the anti-

\footnotetext{
2 For brevity these cells will be designated growth hormone and prolactin cells, respectively.

3 We thank Dr. Ralph F. Knopf, Department of Internal Medicine, University of Michigan, for pro viding the antiserum to human growth hormone and the Endocrinology Study Section of the National Institutes of Health for the ovine prolactin preparation. Also, deeply appreciated is the generous advice provided by Dr. Paul Nakane with respect to the immunochemical staining procedure.
} 
serum altered. However, anti-HGH and anti-RP were ineffective after they were absorbed with rat growth hormone and rat prolactin, respectively. Rat hormones for these absorptions were obtained by electrophoresing homogenates of female (for prolactin) and male (for growth hormone) rat pituitaries on polyacrylamide gel using small blocks of the gel containing the separated growth hormone and prolactin (Baker and Zanotti, '66) for absorption of antisera.

The pituitary glands used for staining were obtained from adult Sprague-Dawley rats. They were fixed in Bouin's fluid, embedded in paraffin and sectioned at $3 \mu$. The donor rats consisted of five males, eight intact females, and six females that had been ovariectomized five weeks previously.

\section{OBSERVATIONS}

When revealed immunochemically with anti-HGH, growth hormone-containing cells were distinctive in many respects. They were frequently aligned alongside sinusoids and many had rounded sides, tending toward an ovoid shape (fig. 1). Some fine granules were delineated but the cytoplasm also stained diffusely (fig. 9). Growth hormone cells were distributed uniformly throughout the pars distalis except for being somewhat less numerous superiorly. After destaining these sections and restaining them with the Masson procedure, the cells reacting with anti-HGH appeared as acidophils in which both fine granules and the general cytoplasm were colored with acid fuchsin and ponceau de xylidene (fig. 10).

Growth hormone cells were larger and more numerous in the adult male (fig. 1) than in the female (fig. 2). In the female they did not change in structure or staining capacity after ovariectomy, although in some loci they were more densely arranged due to reduction in size of the intervening prolactin cells (fig. 3 ).

In contrast to growth hormone cells, prolactin cells varied greatly in shape when demonstrated immunochemically with anti-RP. Although generally polygonal, some were narrow and elongate, appearing to be compressed between other cells (fig. 5). The latter configuration was particularly common alongside basophils. Other prolactin cells were exceedingly large and contained an expanded Golgi area (fig. 11). Large cytoplasmic granules stained more intensely than any other part of the cell. The large granules were usually clustered in the portion of the cell proximal to neighboring sinusoids (fig. 8). From other prolactin cells long processes extended to the sinusoidal walls (fig. 8). Thus, the immunochemical staining reaction for prolactin was most intense in the peripheral granulated parts of the cell and in parasinusoidal processes. Also stained, but much less intensely, were other less granulated areas of the cell, including the Golgi area (fig. 11). After destaining these cells and restaining them with the Masson procedure (fig. 12) it was clear that they represented cells that, when demonstrated by classical staining methods, are commonly recognized as the source of prolactin. Such cells were characterized by sparsely scattered cytoplasmic granules that were the largest of any granules found in acidophils; in many cells the Golgi region was extensive. Thus, it appears that in sections stained with the Masson procedure, growth hormone cells present a uniformly red cytoplasm while in prolactin cells, only the dispersed granules appear red. Although distributed throughout the pars distalis, prolactin cells were especially concentrated immediately proximal to the lateral border of the pars intermedia.

In contrast to growth hormone cells, prolactin cells varied greatly in number and size between the different groups of rats studied. They were large and numerous in hypophyses of normal adult females (fig. 5 ) while in both males (fig. 4) and ovariectomized females (fig. 6) they were smaller and probably less frequent.

Finally, the distinctness of the two acidophil cell types was demonstrated in a single section by staining sequentially for both growth hormone and prolactin by the immunochemical procedure. In such preparations, the two cell types were revealed side by side, appearing brown or red depending on whether DAB or a-naphthol-pyronin, respectively, had been used for their demonstration (fig. 7). They could be differentiated also by chemical staining after 
application of the immunochemical method for one of the hormones (fig. 8).

\section{DISCUSSION}

Dual populations of acidophils. Several observations made in this study verify the concept that growth hormone and prolactin are contained in, and presumably secreted by, different acidophils of the rat hypophysis. First, the cells revealed by immunochemical staining for the two hormones differed with respect to shape and intracellular distribution of the reaction product. In both cell types, the general cytoplasm stained diffusely, this response being more noticeable in the growth hormone cells. However, prolactin cells usually stained more intensely than growth hormone cells and the response was most noticeable in the cytoplasmic areas containing numerous large granules. Association of the staining reaction with the granules indicates that they represent a stored form of the hormone while association of the staining reaction with general cytoplasm suggests that the immunochemical method may also reveal presence of the hormone even though it may not be packaged as a granule.

Immunochemical differentiation of growth hormone and prolactin acidophils in the same section by the use of different substrates for peroxidase provides additional evidence for the individuality of these two cell types. Furthermore, one type probably does not change into the other since no single cell was found to contain both growth hormone and prolactin.

Finally, the concept that growth hormone and prolactin cells are different types, and that the immunochemical staining procedures are specific for them, is supported by the predictable reaction of the cells to differing physiologic conditions. Thus, growth hormone cells as observed in this study were larger and more numerous in the male than in the female. This difference may be explained by the higher total content and concentration of growth hormone in the hypophysis of the adult male rat (Birge et al., '67). Similarly, ovariectomy did not change the size, number, or immunochemical stainability of growth hormone cells although they be- came somewhat more densely arranged in certain areas due to reduction in size of the intervening prolactin cells. This observation may be explained by the failure of previous studies to reveal a conclusive effect of ovariectomy on pituitary content of growth hormone. Although an increase is indicated by the accentuated prominence of the growth hormone-containing protein band in polyacrylamide gel columns after electrophoresis of hypophyseal homogenates obtained from ovariectomized females (Jones et al., '65; Baker and Zanotti, '66), a significant elevation of growth hormone content could not be demonstrated by radioimmunoassay (Birge et al., '67).

With regard to. prolactin cells, their greater number, size and granulation in the female hypophysis as compared with the male may be correlated with the greater concentration of prolactin in the female hypophysis although the total content may be similar (Reece, '37). Also, the striking reduction in size of prolactin cells that follows ovariectomy parallels a concurrent fall in prolactin content (Reece, '37).

Correlation of acidophils revealed by immunochemical and chemical staining. When observed after immunochemical staining, the structural characteristics of both growth hormone and prolactin cells conformed to the features attributed to these cells by other invesigators who used chemical staining and electron microscopy as summarized in the introduction. This correlation was made clear by comparing cells in sections first prepared by the immunochemical method, then destained, and finally restained by the Masson procedure. It was then evident that all Bouinfixed acidophils whose cytoplasm stains uniformly and with varying shades of red following Masson staining are growth hormone cells. On the other hand, all acidophils containing large fuchsinophilic granules are prolactin cells. In addition immunochemical staining for prolactin encompasses other smaller cells, centrally located in cell cords, that may contain fine granules that are near the limit of resolution with the light microscope, or rare large cytoplasmic granules. The possibility that these cells are the corticotropin cells of Herlant ('64) can be elimi- 
nated because corticotropin cells as revealed immunochemically are of exceedingly low incidence and of different morphology (Baker and Midgley, unpublished).

Integration with observations of other workers. Comparison of the observations made here with those of other workers suggests that peroxidase-labeled antibody makes possible a much more precise identification of reactive pituitary cells than can be obtained with fluorescent antibodies. Thus, although no attention was given by Emmart et al. to sex of the rats studied, their illustrations (fig. 4, "63; fig. 5 , '65) show that the great majority of pituitary cells stained positively for prolactin. This observation was supported by Rümke and Ladiges ('65) although they noted that prolactin cells were scattered and not grouped. Our preparations show that in the hypophysis of the adult female rat prolactin cells make up a much smaller percentage of the total cell population.

In conclusion, growth hormone and prolactin cells can be clearly differentiated in the rat hypophysis by immunochemical staining with peroxidase-labeled antibodies. In addition, the reliability of the Masson staining procedure is indicated as a means for demonstrating these cell types in intact adult male and female rats.

\section{LITERATURE CITED}

Baker, B. L., and D. B. Zanotti 1966 Electrophoresis of pituitary proteins after treatment of rats with norethynodrel. Endocrinology, 78: 1037-1040.

Birge, C. A., G. T. Peake, I. K. Mariz and W. H. Daughaday 1967 Radioimmunoassayable growth hormone in the rat pituitary gland: effects of age, sex and hormonal state. Endocrinology, 81: 195-204.

Dawson, A. B., and H. B. Friedgood 1938 Differentiation of two classes of acidophiles in the anterior pituitary of the female rabbit and cat. Stain Techn., 13: 17-21.

Emmart, E. W., R. W. Bates and W. A. Turner 1965 Localization of prolactin in rat pituitary and in a transplantable mammotropic pituitary tumor using fluorescent antibody. J. Histochem. Cytochem., 13: 182-190.

Emmart, E. W., S. S. Spicer and R. W. Bates 1963 Localization of prolactin with the pituitary by specific fluorescent antiprolactin globulin. J. Histochem. Cytochem., 11: 365-373.
Hedinger, C. E., and M. G. Farquhar 1957 Elektronenmikroskopische Untersuchungen von zwei Typen acidophiler Hypophysenvorderlappenzellen bei der Ratte. Schweiz. Z. Path. Bakt., 20: 766-768.

Herlant, M. 1964 The cells of the adenohypophysis and their functional significance. Int. Rev. Cytol., 17: 299-382.

Jones, A. E., J. N. Fisher, U. J. Lewis and W, P. Vanderlaan 1965 Electrophoretic comparison of pituitary glands from male and female rats. Endocrinology, 76: 578-583.

Leznoff, A., J. Fishman, L. Goodfriend, E. McGarry, J. Beck and B. Rose 1960 Localization of fluorescent antibodies to human growth hormone in human anterior pituitary glands. Proc. Soc. Exp. Biol. Med., 104: 232-235.

Masson, P. 1928 Carcinoids (argentaffin-cell tumors ) and nerve hyperplasia of the appendicular mucosa. Am J. Path., 4: 181-212.

Nakane, P. K. 1968 Simultaneous localization of multiple tissue antigens using the peroxidaselabeled antibody method: a study on pituitary glands of the rat. J. Histochem. Cytochem., 16: $557-560$.

Nakane, P. K., and G. B. Pierce, Jr. 1967 Enzyme-labeled antibodies for the light and electron microscopic localization of tissue antigens. J. Cell Biol., 33: 307-318.

Nayak, R., E. E. McGarry and J. C. Beck 1968 Site of prolactin in the pituitary gland, as studied by immunofluorescence. Endocrinology, 83: 731-736.

Niswender, G. D., C. L. Chen, A. R. Midgley, Jr., J. Meites and S. Ellis 1968 Radioimmunoassay for rat prolactin. Proc. Soc. Exp. Biol. Med., in press.

Parker, M. L., L. Jarett, D. S. Schalch and D. M. Kipnis 1965 Rat growth hormone: immunofluorescent and radioimmunologic studies. Endocrinology, 76: 928-932.

Purves, H. D. 1961 Morphology of the hypophysis related to its function. In: Sex and Internal Secretions (vol. 1. W. C. Young, ed.) The Williams and Wilkins Co., Baltimore, pp. 161-239.

Reece, R. P. 1937 The lactogen and thyrotropic content of the anterior lobe of the pituitary gland. Mo. Agr. Exper. Sta. Bull. 266.

Rümke, P., and N. C. J. J. Ladiges 1965 Comparative immunochemical studies with antisera to sheep prolactin and bovine growth hormone on anterior pituitaries of ox, sheep, rats and mice. Z. Zellforsch., 67: 575-583.

Sanders, A. E., and E. G. Rennels 1959 Evidence on the cellular source of Iuteotrophin derived from a study of rat pituitary autografts. Z. Zellforsch., 49: 263-274.

Shiino, M., and E. G. Rennels 1966 Cellular localizations of prolactin and growth hormone in the anterior pituitary glands of the rat and rabbit. Tex. Rep. Biol. Med., 24: 659-673. 
All photographs were taken with Kodak No. 15 and 58 filters. G, growth hormone cell; $\mathrm{P}$, prolactin cell; $\mathrm{S}$, sinusoid.

\section{PLATE 1}

EXPLANATION OF FIGURES

The illustrated areas were located in the central region of the lateral lobe of the hypophyseal pars distalis. The sections illustrated in figures 1-3 were treated with anti-HGH. Those shown in figures 4-6 were treated with anti-RP. DAB was used as substrate to reveal the location of peroxidase-labeled antibody. In order to permit subsequent dehydration and clearing before mounting, the sections were treated with $2 \% \mathrm{OsO}_{4}$ which accounts for most of the background staining. $\times 600$.

1 Male. Growth hormone cells are large and numerous. The cytoplasm stains rather diffusely with some small granules being evident.

2 Intact female. Growth hormone cells are smaller and fewer than in the male (fig. 1).

3 Female, 5 weeks after ovariectomy. In areas where enlarged basophils are infrequent, growth hormone cells are somewhat more densely arranged than in the normal female (fig. 2).

4 Male. Prolactin cells are few and small. Growth hormone cells can be identified in the background by their shape and dense cytoplasm.

5 Intact female. Prolactin cells are polygonal. Portions of the cytoplasm containing large cytoplasmic granules are most intensely stained.

6 Female, five weeks after ovariectomy. Prolactin cells are few in number and small. 

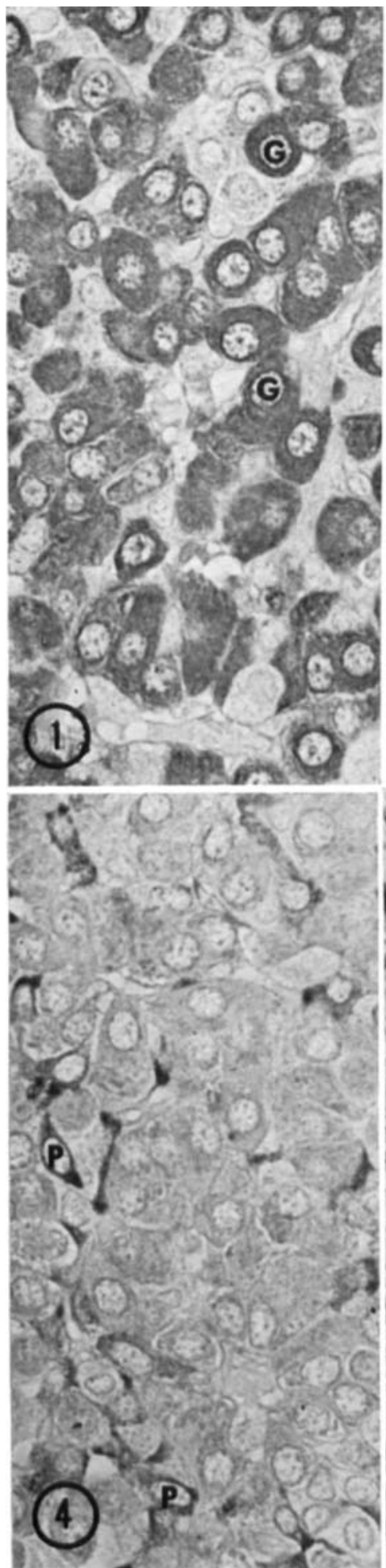
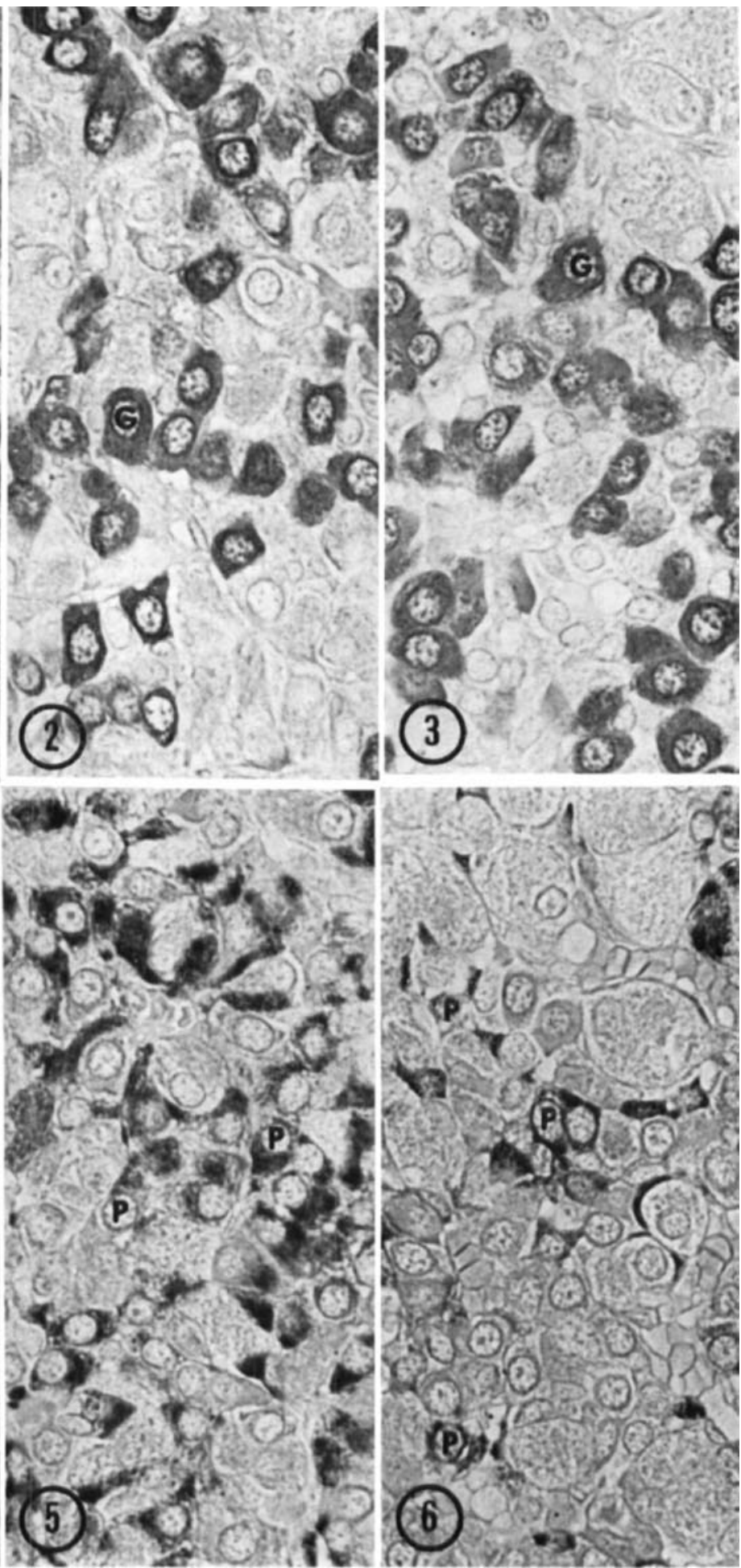
PLATE 2

EXPLANATION OF FIGURES

After staining with a-naphthol-pyronin, differentiation was controlled so that enough pyronin remained in other cells to show general tissue structure (figs. 7-9, fig. 11); pyronin stains nuclei particularly well. The sections represented in these figures were mounted in glychrogel after washing in water.

7 Intact female. Growth hormone cells (brown) were first stained immunochemically with DAB serving as substrate; subsequently, prolactin cells (red) were stained with a-naphthol used as the substrate. $\times 1000$.

8 Intact female. Prolactin cells were stained immunochemically with $a$-naphthol-pyronin. Incomplete extraction of pyronin permitted demonstration of growth hormone cells since they were stained directly and nonspecifically by pyronin. Several granule-filled parasinusoidal processes of prolactin cells are shown (arrows). $\times 1000$.

9 Male. Growth hormone cells are illustrated after application of antiHGH and staining with a-naphthol-pyronin. Small granules as well as the general cytoplasm are darkened. $\times 1000$.

10 Male. After destaining, the section shown in figure 9 was restained with the Masson procedure. Note that all growth hormone cells are revealed by acid fuchsin and ponceau de xylidene.

11 Intact female. Several prolactin cells are shown after application of anti-RP and staining with $a$-naphthol-pyronin. Cytoplasmic granules are stained intensely while the Golgi area $(X)$ is less reactive. A growth hormone cell is not stained. $\times 1500$.

12 Intact female. After destaining, the section illustrated in figure 11 was restained with the Masson procedure with a similar differentiation of cellular structures resulting. The growth hormone cell is stained intensely. $\times 1500$. 

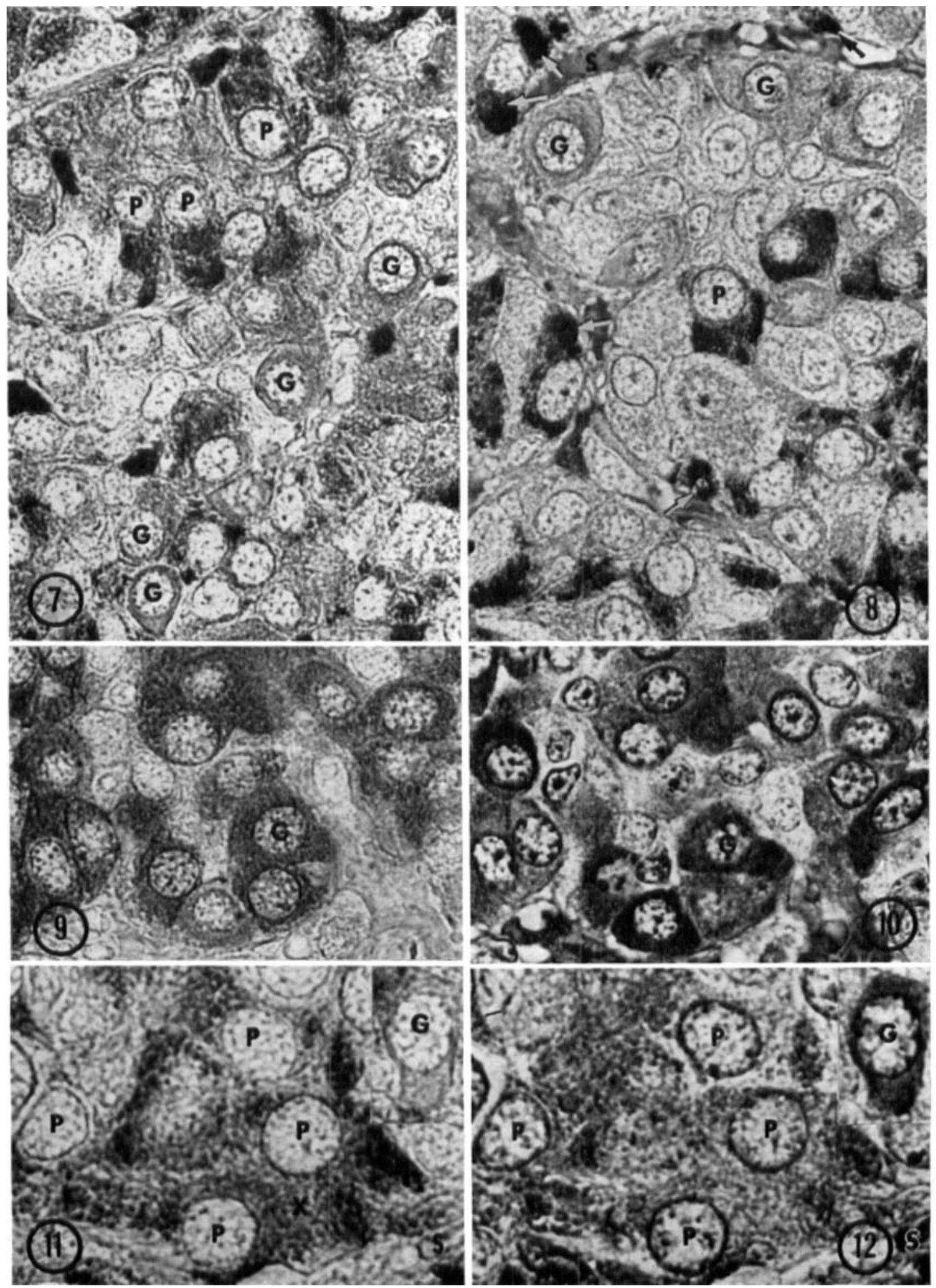